\title{
PUBLIC/PRIVATE APPROACHES TO URBAN MORTGAGE AND HOUSING PROBLEMS
}

\author{
SaUr B. KLamaN*
}

I

Introduction: The Problem and the Setting

\section{A. General Approaches}

In 1965, the establishment of the Department of Housing and Urban Development gave promise of a new era in urban housing policies and programs. In the preceding three decades or so since the Great Depression, federal intervention in housing and mortgage markets had broadened and deepened-through war and peace, through business expansion and contraction. Now, endowed with cabinet status, federal housing policy-makers were given a voice in the highest councils of government. There could be no doubt of the nation's permanent commitment to housing progress in the setting of an improved urban structure. As Dr. Robert Weaver observed, shortly after his appointment as the first Secretary of HUD: "The national role in urban problem-solving is large and growing."

In 1966, however, the nation's housing and mortgage markets were in disarray. The output of new housing fell to a postwar low. Sales of existing housing dropped to uncommonly low levels. Residential mortgage credit virtually dried up, with net mortgage extensions down forty per cent on a year-to-year basis by year-end. New federal urban revitalization programs were lagging for lack of adequate financing. The national role in urban problem-solving, while undoubtedly large and growing, was only marginally effective in the face of devastating short-run problems.

In 1967 , therefore, we have been inundated with proposals to improve the role of government in urban housing and mortgage markets, to make it more effective in short-run as well as long-run urban problem-solving. New federal approaches to long-range urban rebuilding problems, particularly those related to housing for lowincome families, have been urged by legislators, planners, and economists alike. And accompanying the new and renewed public approaches, there have been

* B.S. I94r, University of Massachusetts; M.A. 1942, Michigan State University; Ph.D. 196r, New York University. Vice President and Chief Economist, National Association of Mutual Savings Banks, since 1966; Director of Research 1959-1966; Economist, 1958-59. Staff Economist, Board of Governors of the Federal Reserve System, $1946-58$. Senior Staff Member, Postwar Capital Market Study, National Bureau of Economic Research (1956). Adjunct Professor of Economics and Finance, Bernard Baruch School of Business, City University of New York. Author, The Postwar Residential Montgage Market (Ig6r), The Postwar Rise of Mortgage Companies (r959), The Volume of Mortgage Debt in the Postwar Decade (1958).

${ }^{1}$ Address by Secretary Weaver before the National Press Club, Washington, D.C., Feb. I6, 1966. 
numerous proposals to improve the efficiency of the private market through structural and institutional changes.

\section{B. A Balanced Perspective}

Quite apart from the technical merits of specific approaches to short- and longrun urban problems, it is essential from the policy viewpoint that the relative roles of the public and private sectors be kept in balanced perspective. Federal involvement in the revitalization of our urban environment, in mortgage finance, in housing production and transfer, is clearly great and growing. Private enterprise must surely recognize and accept the key role of government in the building and rebuilding of our urban complex. But government must also appreciate, and indeed welcome, the indispensable role of private enterprise in this gigantic venture.

What is needed, in essence, if we are successfully to revitalize the quality of urban life in America, if we are to find solutions to recurring mortgage and housing problems, is to establish a creative partnership between the private and public sectors of our society. Such a partnership would have its parallel in the "creative federalism" proposed between federal and state and local governments. Such a partnership would seek the realization of broadly accepted public goals through maximum reliance on private means.

It cannot be said, unfortunately, that a well-balanced public/private approach has been characteristic of our urban housing and mortgage programs, policies, and proposals. Among the current maze of mortgage proposals, for example, designed to prevent the recurrence of "another I966," one can detect efforts to insulate or shelter the flow and terms of housing credit from private market forces, efforts to assure, in a sense, an artificially regulated "ever-normal" flow of funds to finance housing needs. Such an approach is doomed at the outset; it presumes the failure of the private market place.

A balanced approach, as envisioned here, must be based on the fundamental premise that insulation of the mortgage sector from the discipline of the private market is neither practical nor desirable. The mortgage sector must be geared to compete more effectively for scarce funds in the forum of the market place, and to release funds to other sectors when the flow of mortgage credit is excessive relative to basic demands. For the flow of credit to be allocated efficiently among competing private market sectors, however, basic adjustments are needed in public policies and programs-federal, state, and local-which influence mortgage flows and housing activity.

Let me stress at this point that the objective of maximizing the participation of the private sector in the revitalization of our cities, and in the modernization of our mortgage structure, is more than just a basic maxim of a private market system. It is a realistic approach to the massive task involved. It recognizes the practicality of using existing private institutional arrangements, funds, and skills. It recognizes 
that major reliance on the public sector for needed funds would severely strain the federal budget and administrative structure. The broad, basic goal of public policy in the mortgage and housing area must, therefore, be to encourage and to supplement-not to preempt-the use of private resources.

Against this general policy setting of public/private approaches to urban housing and mortgage problems, the body of this article is divided into two major segments: (I) tentative solutions to recurring short-run mortgage crises; and (2) longrange considerations of federal urban policy.

II

\section{Tentative Solutions to Recurring Mortgage Crises}

\section{A. The Problems of Plenitude and Shortage}

The r 966 "credit crisis" dramatized the particular vulnerability of the housing and mortgage sectors to cyclical economic change. Earlier periods of credit stringency in the I950s had also demonstrated, although less dramatically, the inability of real estate market participants to compete for scarce funds. But while the most acute problems in the housing credit area have been associated with painful scarcities of funds, they should not obscure the problems associated with excessive mortgage flows. In fact, during the first half of the $x g 60$ s, financial observers were concerned about the deterioration in the quality of housing credit, as mortgage foreclosure rates rose steeply.

In short, the experience of the past decade or so graphically illustrates the unsettling tendency of the residential mortgage sector to swing widely and rapidly from a "plenitude of abundance" to a "plenitude of scarcity." A basic aim of private and public policies, therefore, should be to reduce the volatility of mortgage flows over the business cycle. On balance, this will provide more credit for housing than during alternating periods of feast and famine.

In seeking fundamental solutions, one must identify fundamental causes for the virtual breakdown of the residential mortgage market in 1966 , and for the surfeit of mortgage funds in the preceding years of the ig6os. The more immediate and short-run causes lie in the impact of changing business and financial conditions and of government policies. There is no need to provide a detailed chronology of these events. This is available from several other sources. But a brief review will help set the stage for a discussion of the more fundamental, long-run structural problems.

\section{B. The Immediate Factors}

The economic environment of the early rg6os was conducive to an excessive flow of mortgage credit relative to basic housing demands. Expansionary monetary policies, relative price and interest rate stability, high and rising employment and incomes, and intensified competition for savings accounts, resulted in record deposit 
flows at thrift institutions and commercial banks. Because of their restricted loan and investment powers, thrift institutions-particularly savings and loanschanneled their record-breaking saving flows into mortgage markets, even though overall housing demands were relatively sluggish. And commercial banks in this period, faced with the high costs of time deposits in a period of inadequate business loan demand, turned strongly to home mortgage loans (together with municipal securities) as a source of income.

The result was a greater acceptance of marginal credit risks, steadily liberalized mortgage contract terms, excessively high property appraisals, and encouragement of marginal building operations. The quality of credit was clearly being strained. Evidence of deterioration was later apparent in mounting mortgage delinquencies and foreclosures, and in the rising "scheduled items" at several savings and loan associations. ${ }^{2}$

By mid-1965, the situation had changed significantly, however, culminating in the near credit crisis of late $\mathrm{r} 966$. With the nation's physical and human resources virtually fully employed, continued vigorous business expansion put the economy under severe strain. Persistent credit demands from business, governments, and consumers pushed open market interest rates to the highest levels in forty years by late summer of 1966 . Of course, this was due in part to the especially restrictive monetary policy stance taken by the Federal Reserve Board. In the absence of adequate fiscal restraints, severe monetary stringency was employed as the only effective anti-inflationary weapon.

In this environment, saving flows fell sharply at thrift institutions, where deposit interest rates were not competitive with open market yields or with special commercial bank savings instruments. Savings and loan associations sustained a fiftyseven per cent drop in net saving flows between 1965 and 1966 . Their 1966 flow was the smallest in fourteen years and less than the amount of dividends credited to savings accounts. At mutual savings banks, I 966 deposit flows were down twentynine per cent from 1965 , with the bulk of the gain reflecting the crediting of interestdividends.

In marked contrast to developments at mortgage-oriented institutions, saving flows into commercial banks held up quite well in I966, falling only about thirteen per cent from the high 1965 level. The ability of commercial banks to turn over short-term assets quickly, and invest in new high-interest obligations, permitted them to pay attractive rates to depositors. The result was soaring sales of savings certificates and other consumer-type time deposits which substantially offset reduced gains in regular passbook savings, bearing relatively low rates under Regulation $Q$ ceilings. ${ }^{3}$ And except for the regulatory roll-back of "consumer $\mathrm{C} / \mathrm{D}$ " interest

\footnotetext{
${ }^{2}$ Preliminary findings of a National Bureau of Economic Research study on quality of credit (not available for publication at this time) confirm the deterioration in credit quality in the early 1960s.

${ }^{3}$ See 12 C.F.R. $\$ 217.6$ (Supp. I966).
} 
rates in September 1966, commercial bank saving flows would undoubtedly have been larger.

All three major deposit-type institutions, of course, were locked in competitive battle with high-flying capital market instruments. These were the immediate cause of the dramatic "disintermediation" of 1966 . Individuals channeled a record \$1 billion into all types of credit and equity market instruments-more than four times the I 965 volume. They supplied directly almost one-sixth of the nation's total credit demands in 1966, the highest share since 1957, compared with less than four per cent in 1965 .

In the face of sharply reduced saving flows, and mounting pressures on earnings and liquidity positions, mortgage-oriented savings institutions drastically cut back their new mortgage activity in 1966 . Other credit markets remained well supplied, however, partly because of the direct investment activity of individuals. The severity of the mortgage cutback reflected also the large volume of outstanding mortgage commitments and inventory of "warehoused" mortgage loans overhanging the market. These technical factors intensified pressures on institutional lenders to curtail new commitments as saving flows turned sharply downward in I966.

New home mortgage commitment and lending activity was also cut back by life insurance companies in the face of sharply rising bond yields and lucrative returns on income-property loans. Heavy demands for policy loans and reduced home mortgage repayments in the stringent 1966 environment, moreover, reduced cash flows available for home mortgage lending.

All things considered, the immediate factors underlying the 1966 "mortgage crisis" were the unbalanced mix of monetary and fiscal policies, the selective impact of severe financial stringency on mortgage-oriented savings institutions, and the reinforcing influence of technical mortgage market factors. Under these circumstances, curtailed savings growth was quickly translated into sharply reduced mortgage and residential real estate activity. Conversely, in the earlier xg6os when financial ease and relatively low market interest rates stimulated savings growth, mortgage flows soared to excessive levels, relative to housing demand, because savings institutions were limited in their alternative investment opportunities. (The course of these financial developments and their impact on mortgage and housing markets is traced in figure $\mathrm{I}$.)

\section{Structural Problems and Programs}

Underlying the immediate causes of recurring "mortgage crises," summarized above, are deep-seated structural problems. And as long as these remain uncorrected, mortgage flows, housing activity, and urban rebuilding will remain susceptible to significant cyclical swings in the changing economic environment. The greater danger in the years ahead, perhaps, is of a sustained shortage, rather than 


\section{FIGURE I}

Financial Developments Leading to Mortgage Stringency and Housing Declines in 1966

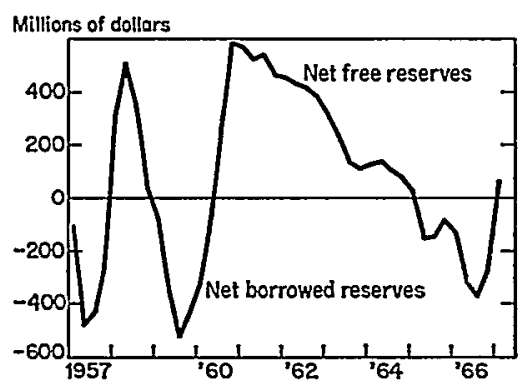

A. Excessive reliance on monefary policy to combat inflation in 1966 brought....

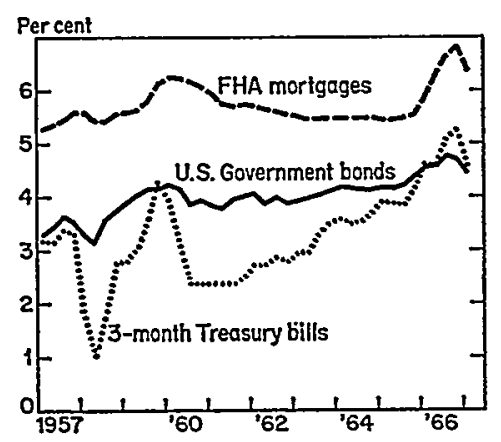

B. Soaring interest rates ...

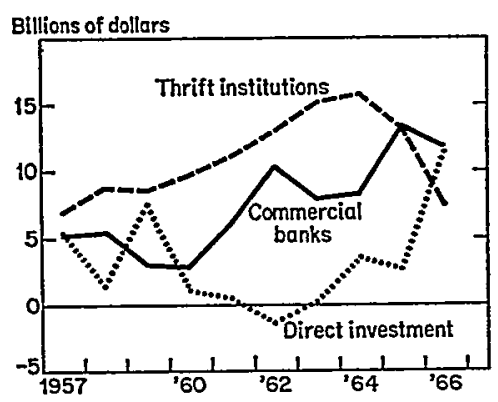

C. Massive saying shifts and ...

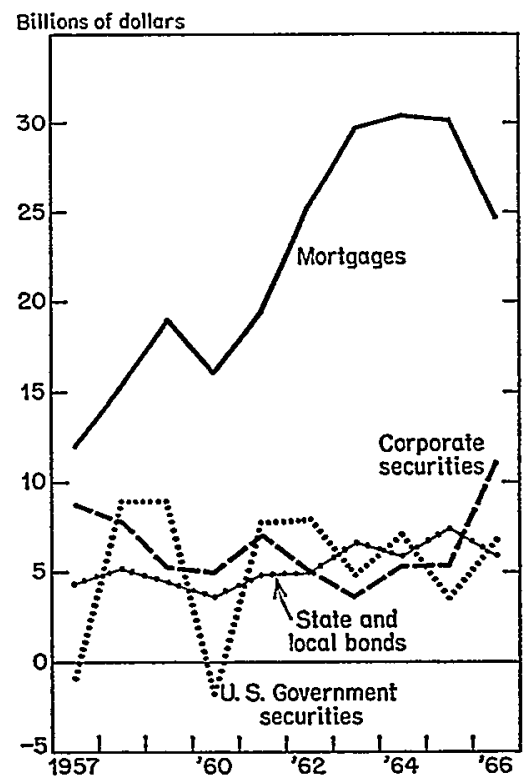

D. Mortgage flows fell sharply and corporate and U.S. Government security issues rose substantially.

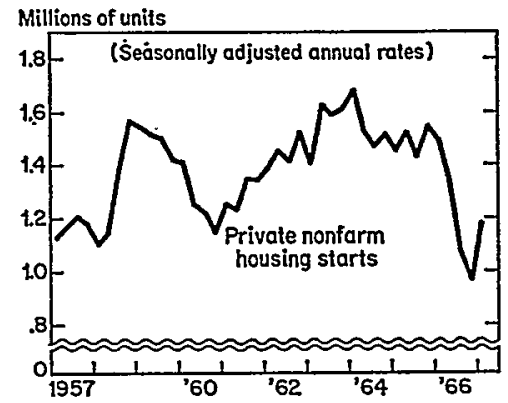

E. Housing starts declined to a postwar low.

Source: Nat'l Ass'n of Mutual Savings Banks ANw. Rep. 3, 5 (Ig67). 
plenitude, of housing credit in the face of heavy capital demands for private and public purposes. But whether the long-term trend indicates shortage or adequacy of housing credit, the unsettling effects of cyclical mortgage instability, arising out of structural problems, remain an ever-present danger.

What then are the basic structural problems which adversely affect the flow of residential mortgage credit? In my judgment, they lie in three related areas: (I) the fundamentally changing nature and inadequate structure of savings markets; (2) the cumbersome nature of the mortgage instrument itself; and (3) the unrealistic federal-state regulatory and statutory framework in which the mortgage market functions.

These interrelated problems call for an interrelated, integrated three-part program

(I) to adapt existing mortgage-oriented savings institutions to the changed financial environment,

(2) to tap supplementary sources of mortgage credit through new market instruments, and

(3) to adjust the role of government to the realities of the private market place.

\section{x. Adapting Savings Institutions}

Any program to strengthen and stabilize the flow of home mortgage credit in the economy must be firmly anchored to the strengthening of mortgage-oriented savings institutions. These institutions are, and will remain, the major suppliers of home mortgage credit. When their inflow of savings is sharply reduced, as in I966, so also is the flow of home mortgage credit. When their saving inflows are large relative to suitable mortgage outlets, the quality of credit is threatened. Moreover, dislocations generated in one period reinforce the problems of the next.

Improvement in the competitive strength and flexibility of thrift institutions requires the restructuring of both their assets and liabilities. Savings institutions must modify their "borrowing short lending long" policies. They cannot continue, in effect, to promise "instant liquidity" from a basically illiquid balance sheet.

On the liabilities side, therefore, savings institutions must reduce their reliance on the standard passbook savings account to attract funds. They need to supplement these accounts with a variety of higher-yielding saving plans which will limit depositor liquidity, space out depositor claims, and offer higher rates for incremental than for existing savings. Such plans will result in greater flexibility, better control over withdrawals, reduced pressures on earnings, and increased competitive ability to attract savings. Several supplementary savings plans have been developed in recent years and are already in use, but on too limited a basis, both with respect to amount of deposits and number of institutions.

Savings institutions must greatly expand the use, and innovate in the development, of such savings plans as (I) investment-type accounts, including savings 
certificates, (2) limited withdrawal accounts, requiring sixty to ninety days or more notice, (3) split rate plans with higher rates for long-term accounts, (4) systematic saving plans, with bonuses for regular saving over a period of years, and (5) annuitytype plans pointing toward regular payments in retirement years. In addition, savings institutions must explore the possibilities of issuing debenture-type obligations in the open market to raise funds.

On the assets side of the balance sheet, savings institutions must be permitted broadened loan and investment powers. On the surface, this may appear an anomalous solution to mortgage credit problems, but it is essential to strengthen the structure of the major mortgage credit suppliers. Broadened powers would increase the viability of savings institutions, permit a more rapid adjustment of earnings to rapid interest rate advances, enhance their ability to compete for savings with commercial banks and open market instruments, and hence permit them to meet more effectively basic demands for mortgage credit in the economy. In essence, broadened investment opportunities for savings institutions would mean first, lessened investment risks and increased ability to strengthen long-run earning power and promote thrift continuously. This is so because funds could be allocated more readily among competing investments in accordance with highest yields (consistent with safety and liquidity) while earnings would be more responsive in periods of rapid financial change. These broadened investment opportunities would also mean a more stable flow of mortgage funds over the business cycle. This is so because excessive mortgage credit expansion in periods of relatively low housing demand or rapid savings growth would be avoided, while in other periods, demands for mortgage credit in excess of savings growth could be met by the conversion of short-term loans and other assets into mortgage loans.

These basic facts have been recognized by distinguished observers of the contemporary financial and economic scene. In a recent speech, Federal Reserve Governor Andrew F. Brimmer noted:4

A shift to broader lending capabilities by the savings and loans and savings banks... would create more general strength among financial institutions to adjust to monetary stringency and thus help to spread the impact of monetary actions more evenly throughout the financial sector.

And, in their I967 Annual Report, the President's Council of Economic Advisers, recommending federal charters for mutual savings banks, commented: ${ }^{5}$

While broadened investment privileges of federally chartered mutual savings banks might initially divert some funds from the mortgage market, such chartered banks would improve the efficiency of thrift institutions, strengthen them in competition with banks, and thereby ultimately benefit the mortgage market.

\footnotetext{
'Address by Governor Brimmer, Annual Meeting of the Town Hall, Los Angeles, Cal., March 21, I967.
"I967 Council of Ecovomic Advisers ANN. Rep., in 1967 Economic Report OF THE President 27, 67.
} 
The tangible advantages of asset flexibility for the mortgage market can be seen clearly in the 1966 experience. Savings banks, with broader powers than savings and loans, were able to channel 108 per cent of their net deposit gains into mortgage loans. This was possible because inadequate deposit flows were supplemented by funds from conversion of other assets and from repayments of non-mortgage loans. Savings and loan associations, however, limited almost entirely to home mortgage lending, were able to channel only eighty-four per cent of their net increase in savings and borrowings into mortgage loans. These developments were explicitly recognized by the Federal Reserve Board, in its I 966 Annual Report: ${ }^{\circ}$

While reduced net inflows at savings banks led to some reduction in mortgage commitments and acquisitions, these declines were less severe than at savings and loan associations. The ability of the mutual savings banks to better maintain their mortgage acquisitions reflected not only their deposit experience but also their more diversified portfolios, which permitted them to liquidate other securities in order to limit the reduction in their mortgage lending.

Parenthetically, commercial banks placed only thirty-eight per cent of their net savings and time deposit growth into mortgages, reflecting their fundamental orientation towards the business loan sector.

While savings banks do have broader powers than savings and loans, both are quite limited compared with commercial banks. Many savings banks and nearly all savings and loans, for example, are denied the right to make consumer loans. Basic legislation is required to achieve the desired broadening of powers. Such legislation is now at hand in the form of the federal savings bank bill, ${ }^{7}$ sponsored by the administration and now before the Congress. This bill authorizes flexible loan and investment powers for federally-chartered savings banks and provides for the conversion of savings and loan associations into federal savings banks. The federal savings bank bill appears to offer a sound and practical route to the achievement of a strengthened mortgage-oriented system of savings institutions.

\section{Supplementary Mortgage Sources Through New Credit Instruments}

If mortgage markets are to function more effectively, additional sources of credit should be developed to supplement flows from traditional lenders, who will remain the major source of funds. This objective will not easily be fulfilled, considering the legally complex, economically cumbersome structure of mortgage finance.

The mortgage instrument reflects the complicated system of real estate transfer and the highly differentiated, localized nature of real estate markets. To be sure, government underwriting, through FHA insurance and VA guarantee, has given the mortgage loan some of the attributes of a modern credit instrument-uniformity

\footnotetext{
' 53 Board of Governors of the Federal Reserve System Ann. Rep. 60 (1966).

${ }^{7}$ S. 1955, 9oth Cong., Ist Sess. (1967); H.R. 10745, 90th Cong., Ist Sess. (1967).
} 
and transferability. But even so, federally underwritten loans are not readily classifiable or broadly marketable, or unfettered by technical servicing problems.

Nor does legislating some super-secondary market institution into existence to provide "instant liquidity" offer an all-purpose solution to the need for broadened credit sources. Even the multi-billion dollar, government-sponsored, Federal National Mortgage Association (FNMA) severely rationed secondary market transactions in 1966 , because of fund limitations.

The difficulties notwithstanding, the advantages of dependable, supplementary sources of mortgage funds in periods of credit stringency are so great that the effort is worth making. Consumers and pension funds, in particular, represent two broad investor groups which could be attracted into mortgage investments if suitable types of credit instruments are developed.

In the case of consumers, there is ample evidence of their willingness to invest directly in capital market instruments when yields are attractive relative to risk and liquidity. As noted previously, consumers invested a record \$II billion in open market securities during 1966 , four times the 1965 volume. Needless to say, if part of this large flow could have been attracted into the mortgage sector, the burden of financial stringency would have been more evenly shared, and severe economic dislocations would have been lessened.

But the mortgage instrument and marketing channels are not now geared to attract the sophisticated individual investor. There is need for a security-type mortgage instrument that would be competitive with other capital market securities. In broad terms, such an instrument should be (I) made available in as wide a variety of denominations and maturities as are other open market securities, (2) so designed as to minimize competition with savings deposits and maximize competition with other capital market instruments, and (3) marketed through privately-financed companies, organized perhaps as subsidiaries of financial intermediaries which would purchase mortgages from the intermediaries and, in turn, sell securities to the public backed by these mortgages.

In short, a relatively small-denomination, consumer-type mortgage participation is required that would command public respect and confidence. A repetition of the unhappy investor experience with mortgage guarantee bonds of the Ig20s can be avoided. In this regard, one need only note the favorable public reception to participation certificate offerings of FNMA and the Export-Import Bank in recent years. The successful marketing of these instruments, which represent beneficial interests in pools of government-owned assets, including mortgages, strongly suggests that, under the right conditions, consumer response to a mortgage-type security would be favorable.

A similar type of security-but in much larger denominations-could also attract pension funds unwilling to deal in the cumbersome mortgage instrument itself. There is already evidence that a large-denomination trust certificate, secured by a 
portfolio of federally underwritten mortgages, is being developed by mortgage bankers for purchase by selected pension funds. If this approach proves feasible, it will undoubtedly be more widely adopted.

\section{Adjusting the Role of Government to Market Realities}

Finally, at both the state and federal level, more realistic governmental policies are needed to bring the mortgage market firmly into the twentieth century. Longstanding variations in state mortgage statutes governing foreclosure procedures, redemption periods and "doing business" penalties continue to hamper mortgage market operations. As a practical matter, however, it is probably unrealistic to expect significant improvement in these areas soon.

Shifts in state and federal attitudes toward interest rates, however, are within the realm of possibility. There are at present ten states which impose a six per cent interest rate ceiling on mortgage loans. Such usury laws, enacted years ago, are clearly in need of revision, with the prime rate at this level in 1966 and federal agencies paying as much to borrow. Otherwise, severe dislocations will continue to occur in local mortgage markets, as funds are diverted from low-interest-ceiling states in periods of credit stringency.

The statutory interest rate ceiling on FHA-insured and VA-guaranteed loans is also at six per cent, and rates up to this level are established by administrative action. Discounts from contract rates are permitted, of course, but under such restrictive circumstances that federally underwritten mortgage flows and real estate transactions are, as in 1966, severely affected when the general level of interest rates is high and rising. The economic logic for completely free FHA and VA rates is unassailable, but the political barriers seem equally impenetrable. After years of unsuccessful effort by many groups, I am prepared to concede that a free market rate for FHA and VA loans is probably not attainable in the foreseeable future.

It does seem feasible, however, to achieve greater flexibility of FHA and VA contract interest rates by

(I) requiring the Secretary of Housing and Urban Development to adjust contract interest rates so as to minimize discounts at all times, even to the extent of lifting the contract rate above six per cent when necessary,

(2) modifying the restriction that mortgage discounts cannot be recognized in the price of properties, and

(3) relating FHA and VA mortgage rates to the movement of long-term U.S. Government bond yields.

The last point runs into the difficulty of determining suitable yield spreads, of course, particularly if regional mortgage rate variations are to be taken into account. But the current uniform contract rate allows for no regional variations. The possibility 
of some increased interest rate flexibility, therefore, even on an imperfect basis, is most appealing.

Among other possible federal policy adjustments, FNMA should not arbitrarily restrict its secondary market purchases on the basis of loan size and date of origination. Such restrictions, in effect, inequitably cut off higher-priced areas from access to FNMA, as well as mortgage holders from selling existing loans to FNMA. In a market economy, price should be more heavily relied on as the basic technique for rationing scarce funds to the market place, and the liquidity needs of lenders should not be so patently ignored. To do otherwise fails to recognize the interrelationship of new and existing house markets, and significantly weakens the role of FNMA as a secondary market facility.

In sum, there is no single dramatic panacea for the problems which periodically beset the mortgage market. A series of basic steps along the lines suggested here seem to encompass a realistic approach-a broad-based attack on a multi-faceted problem, with each segment reinforcing the other. Moreover, it should be emphasized that the overriding goal of policy and programs should be to help the mortgage market function more effectively within the private market place and not to shelter it from the discipline of overall credit availability and price as determined by private market forces.

\section{III}

\section{Public/Private Balance in Urban Revitalization}

\section{A. The Cost/Benefit Principle}

At the outset of this article, it was suggested that effective solutions to urban mortgage and housing problems must rest on the creative partnership of the private and public sectors. In this respect, it was stressed that a basic goal of public policy must be to encourage and to supplement, not to preempt, the use of private resources.

A related principle of sound urban problem-solving, which must be recognized at this point, is the cost/benefit balance in public finance. For this principle to be observed in urban programs, it is clearly necessary for public financial assistance to be openly recognized and disbursed so that costs incurred may be directly measured against benefits achieved.

Unfortunately, this fundamental principle has not always been observed in federal housing policy. Indeed, political expediency or other non-economic criteria have as often dictated policy as long-range criteria of appropriate private/public or cost/ benefit balance. This has meant that the approach of federal housing and urban revitalization programs has not infrequently been piecemeal and uncoordinated. It has meant the accumulation of federal aids, including direct grants, loans, and mortgage insurance, in programs which have tended to supplant, rather than to supplement, private credit. And it has meant that costs have too often been obscured, while concentrating on benefits obtained. 


\section{The Submarket Interest Rate Approach: A Violation of Basic Precepts}

One basic approach to housing problems which violates both criteria of maximum private participation and cost/benefit balance is the use of "submarket" interest rates in federally underwritten mortgage lending programs. This approach of making credit available at rates well below the private market is used to subsidize housing costs for low- and middle-income families. It is widely recognized, of course, that such below-market rate loans insured by the Federal Housing Administration and "purchased" by the Federal National Mortgage Association represent a thinlydisguised substitute for direct federal lending.

Admittedly, the submarket rate approach to housing problems is an administratively convenient and politically expedient device to achieve subsidies for families unable to compete in the private market place. But in the long run it is a snare and a delusion. It does not permit the use of private credit, so desperately needed to supplement public funds if low-cost housing programs are to expand significantly. It effectively obscures actual subsidy costs, so necessary to judge the efficiency and usefulness of the program relative to benefits achieved.

I regard the submarket interest rate approach as bad public policy even when associated with direct federal loans. Such loans, sometimes essential to fill a private housing credit gap, ought to be offered at going rates of interest-consistent with federal borrowing costs at least-to borrowers unable, for one or another reason, to secure private funds on competitive terms. Another dimension is added when hidden cost subsidies, as well as direct public credit, are provided through the submarket interest rate technique.

If interest rate subsidies-in addition to public credit-are deemed sound public policy, they should be provided directly and accepted as a measurable social cost. One way of doing this is to have private lenders extend credit at market rates of interest, with the difference between the market rate and subsidized rate to borrowers paid directly to financial institutions by government. In this way, private credit sources would be tapped (reducing the need for public funds) and the actual subsidy costs (interest rate differential) of the program would be directly measurable.

In sum, current submarket interest rate housing programs ought to be gradually eliminated because (I) they preempt rather than supplement the use of private credit, and (2) they obscure actual subsidy costs and thus hinder their measure against benefits achieved.

\section{The Rent Supplement Approach: In Support of Basic Precepts}

In sharp contrast to the below-market rate program, the relatively new rent supplement program directly supports sound basic principles of public policy in urban revitalization. In this program, maximum reliance is placed on the private sector to achieve a desired public objective. The rental housing provided for low-income 
families is privately built, privately owned, and privately financed, at market prices and interest rates. And, the supplemental rent payments represent subsidy costs openly measurable against benefits received, not obscured through hidden interestrate subsidies in federal credits.

When the rent supplement program was proposed in 1965 , there was at long last implicit federal recognition that both the concept and practicality of the submarket interest rate approach were found wanting. In transmitting the Housing and Urban Development Act of Ig65 to the Congress, President Johnson said: ${ }^{8}$

Up to now Government programs for low- and moderate-income families have concentrated on either direct financing of construction; or on making below-themarket-rate loans to private builders. ...

....

... If [the rent supplement program] works as well as we expect, it should be possible to phase out most of our existing programs of low-interest loans.

The President, in his 1965 message on the central city and its suburbs, also stated: "[W]e must recognize that the benefits of [below-market interest rate programs] are decreasing as the rising costs of Federal borrowing narrows the difference between the interest we ask and that demanded in the private market."

When they were made two years ago, these statements represented, in my judgment, a major step forward in the direction of federal housing policy-a significant turn towards increased reliance on the private sector. I was aware, of course, of the practical problems of discontinuing submarket interest rate programs before the rent supplement and other proposed private/public direct subsidy programs had been proven successful. Now, two years later, I must confess to some disappointment.

The rent supplement program has run into serious congressional obstacles. Its concept is not fully appreciated, its working apparatus considered discouragingly complex. As a result, the program has been operating on minimum funds. Until this program is well funded and given an opportunity to prove its worth, the submarket interest rate program, unfortunately, is likely to remain the basic approach to the low-income housing problem, in violation of fundamental principles of private/ public partnership and cost/benefit balance.

\section{B. The Concept and Philosophy of Federal Mortgage Insurance}

In the broad range of urban programs, current and proposed, one of those longest in operation stands out as the epitome of the creative partnership between the private and public sectors. I refer, of course, to federal mortgage insurance, established over three decades ago, and operated so successfully through the Federal Housing Administration. With respect to the cost/benefit balance, moreover, the FHA program is entirely self-sustaining through income from insurance premiums. On

\footnotetext{
${ }^{8}$ H.R. Doc. No. 99, 89th Cong., Ist Sess. 7-8 (I965).

'Id. at 9 .
} 
both counts, then, federal mortgage insurance deserves to be the principal credit aid in the revitalization of our cities.

There is a body of private market opinion, however, which disagrees with this view. It holds that for FHA to assume the high risks inherent in urban rebuilding programs is to forsake the basic business principle underlying its creation-the insurance of economically sound residential mortgage credits. In this view, the fundamental concept and philosophy of federal mortgage insurance is violated when FHA moves into areas outside of standard single-family housing and multi-family projects.

This is a rather parochial and short-sighted position to take, however, in a rapidly changing urban scene. It confuses purposes and objectives with specific programs undertaken to attain them. It will be recalled that the FHA was etablished in the depths of the Great Depression (1934) to stimulate the construction of new housing and the repair and modernization of existing housing, in part to provide new employment opportunities. Federal mortgage insurance was the new tool invented to encourage the flow of private credit into markets which, in retrospect, had proven to be excessively risky. The approach was new, daring, and imaginative; the objective was to renew and broaden the residential mortgage market with a viable, modern credit instrument. The cornerstone and prerequisite of the new federal mortgage insurance program was "economic soundness."

In the almost uninterrupted three-decade rise in real estate values which has followed its establishment, FHA has become a resounding business success. Its philosophy, concepts, and objectives have been proven sound. And once proven, they have been embraced by private lenders and investors, now entering markets not earlier dared without federal mortgage insurance.

In today's new urban environment, with its new problems and needs, however, FHA's principal concept and objectives are not well served by continuing to plow old fields, by operating solely in already proven markets, such as single-family suburban housing. Only by pursuing new programs, in fact, does FHA fulfill its original purpose-to open up new markets and opportunities with private resources, which otherwise might be long deferred or developed eventually only with public funds.

In essence, FHA serves its most useful-and originally intended-function when it operates on the frontiers of housing and mortgage markets. It must innovate. It must be cognizant of changing market patterns and unmet needs and, through the insurance technique, channel resources into areas where private industry still fears to tread alone. To follow this course is to break new paths in the original FHA tradition. Not to follow it is to retrogress into a shell of safe, proven markets until the fundamental reason for federal mortgage insurance disappears.

In this frame of reference, no program is better suited to the fulfillment of FHA's basic principles and objectives than the urban revitalization program. And 
no technique is better suited than federal mortgage insurance-at market rates of interest-to maximize the use of private resources to achieve broadly accepted public goals.

Few tasks have greater economic and social significance than the rebuilding of our urban complex. And few tasks confront private lenders and investors with greater risks in their initial stages of development. These ingredients are tailor-made for the use of federal risk-sharing aids. Once urban rebuilding programs are proven economically sound, the willingness of private industry to participate alone will increase and the need for federal assistance will be reduced.

The acceptance of greater risks inherent in broad new urban programs means, of course, that a larger proportion of the contingent liabilities borne by the federal government through mortgage insurance may ultimately turn into real liabilities. But this is a burden that a federal insurance agency and the American community should be willing to bear, if the objective sought is worth the risk entailed. The logic appears unassailable, then, that federal mortgage insurance ought to be centered on those urban investments which are riskier than alternative private market opportunities but which have a strong long-range base of economic soundness.

\section{The Need for a Public/Private Administrative Structure}

In concluding this article, I cannot resist the temptation of dusting off an administrative proposal, which I have had occasion to recommend elsewhere. There is a need for a voluntary public/private administrative network-at national, state, and local levels-in which public agencies and private groups jointly plan, develop, and implement programs and policies for urban rebuilding. Such an administrative structure might operate within "Councils of Urban Rebuilding Enterprises" (CURE). This would give specific administrative recognition to the existence of a creative public/private partnership. The existence of CURE, moreover, would recognize that private institutions have more to contribute than money to the massive task of urban revitalization. They have imaginative and technical skills as well.

Such a creative public/private structure is, of course, not an entirely new concept. Similar administrative arrangements have been adopted before at various levels of government and with various degrees of success. There is much that can be learned from the function of these earlier administrative arrangements-both the successful and unsuccessful. The important thing is that through a continuing, cooperative administrative organization, old battle lines between public and private forces might more quickly disintegrate. This, of course, is the essential ingredient to the forging of a meaningful, operative, public/private partnership. 